\title{
Impact of Socio-Cultural Factors on Antenatal Practices
}

\author{
${ }^{1}$ Madhusudan Ghimire, ${ }^{2}$ Gyanendra Gautam, ${ }^{1}$ Moushami Ghimire, ${ }^{3}$ Tara Devi Sharma, ${ }^{4}$ Bimala Sharma \\ ${ }^{1}$ Department of Community Medicine, Lumbini Medical College, Palpa, Nepal \\ ${ }^{2}$ Department of Microbiology, Gandaki Medical College, Pokhara, Nepal \\ ${ }^{1}$ Department of Community Medicine, Lumbini Medical College, Palpa, Nepal \\ ${ }^{3}$ Dietician, Gandaki Medical College, Pokhara, Nepal \\ ${ }^{4}$ Department of Community Medicine, Gandaki Medical College, Pokhara, Nepal
}

\begin{abstract}
:
The provision for special care during pregnancy through public health services is considered by World Health organization as a part of reproductive health right of women which, however, is not achieved till date due to socio-cultural factors resulting increased maternal morbidity and mortality. The objective of this study is to observe impact of socio-cultural factors on antenatal practices. The study was conducted in three Village Development Committees (Dakhaquady, Khaira, and Belbash) of Pyuthan district. During the period Cross-sectional study was followed. Two hundred forty six respondents were selected through simple random procedure. Interview schedules were used to collect information from respondents. Data were tabulated in Microsoft Excel spreadsheet and analyzed using SPSS 11.5. The mean age of first pregnancy among respondents was 18.75 years. Forty-two percent of them were illiterate and 76.90 percent respondents were involved in agricultural field work. Early marriage and pregnancy systems were most common in study population. Socio-cultural factors were strongly associated with ANC practices.
\end{abstract}

Key words: ANC practices, early marriage, early pregnancy, Pyuthan, socio-cultural factors, traditional beliefs.

Corresponding address: Gyanendra Gautam, Department of Microbiology, Gandaki Medical College and Teaching Hospital, Kaski, Nepal. E-mail: gautamgyanendrapokhara@gmail.com

\section{INTRODUCTION}

Socio-cultural premise may be conscious as well as unconscious assumption which is not clearly verbalized but it may be more powerful in its effect upon the thinking, feeling and action of the individual. ${ }^{1}$ The socio-cultural practices as attitude to marriage, age at marriage, the value attached to fertility, sex of the child, the pattern of the family organization, ideal role demanded of women by social convention, social hierarchy, education, social custom/belief and cultural attitude, family health and economic status, decision making, women's multiple role in society, family relationship, administrative and political systems, division of labour by sex and occupation may have immense effect on women's reproductive health and it's components. ${ }^{2}$ The primary aim of the antenatal care is to have a healthy mother and a healthy baby at the end of pregnancy. The antenatal care can be performed at home and/or in the clinic once a month during first seven months of pregnancy, twice a month during eighth month and then weekly in the ninth month. Detail examination should be done by the public health nurse, lady health visitors, female worker, or the midwife as well as at least one examination should be done by related export. ${ }^{3,4}$

\section{MATERIALS AND METHODS}

The study was conducted in three Village Development Committee as: Dakhaquady, Khaira, and Belbash in Pyuthan District. An analytical cross sectional study was applied and 246 pregnant women were selected through simple random sampling. Mainly pre test interview schedule was used to collect information. Data were collected through face-to-face interview procedure. Special care was taken for maintaining ethical issues during time of data collection and anonymity of all participants was maintained. SPSS Microsoft process was applied for analyzing information.

\section{RESULTS}

Table 1: Distribution of education, occupation and physical facilities $N=246$

\begin{tabular}{|l|l|l|}
\hline \multirow{4}{*}{ Education } & & Frequency (\%) \\
\cline { 2 - 3 } & Illiterate & $103(41.5)$ \\
\cline { 2 - 3 } & Primary & $75(30.5)$ \\
\cline { 2 - 3 } & Lower secondary & $27(11)$ \\
\cline { 2 - 3 } & SLC & $24(9.8)$ \\
\cline { 2 - 3 } & SLC above & $17(7.2)$ \\
\hline \multirow{5}{*}{ Occupation } & Agriculture & $189(76.9)$ \\
\cline { 2 - 3 } & Business & $23(9.3)$ \\
\cline { 2 - 3 } & Teacher & $12(4.9)$ \\
\cline { 2 - 3 } & Daily labourer & $22(8.9)$ \\
\hline
\end{tabular}

The study found that $41.50 \%$ of total pregnant women were illiterate. Near about one third (30.5\%) respondents got primary level of education that could write and read only Maximum respondents $(76.90 \%)$ of total participants were involved in agricultural work as well as $8.90 \%$ were involved in hard work. 
Table 2: Distribution of age at marriage and first pregnancy of respondent $N=246$

\begin{tabular}{|c|c|c|c|c|}
\hline \multirow[t]{5}{*}{ Age at marriage } & Age in years & Frequency $(\%)$ & Mean & $\begin{array}{l}\text { Std. } \\
\text { Dev }\end{array}$ \\
\hline & Unknown & $6(2.6)$ & \multirow{4}{*}{-} & \multirow{4}{*}{-} \\
\hline & $<15$ & $45(18.3)$ & & \\
\hline & $16-20$ & $147(59.8)$ & & \\
\hline & $>20$ & $48(19.5)$ & & \\
\hline \multirow{8}{*}{$\begin{array}{l}\text { Age at First } \\
\text { pregnancy } \\
\text { (Age in year) }\end{array}$} & 16 & $30(12.2)$ & \multirow{8}{*}{18.7} & \multirow{8}{*}{1.9} \\
\hline & 17 & $51(20.7)$ & & \\
\hline & 18 & $36(14.6)$ & & \\
\hline & 19 & $48(19.5)$ & & \\
\hline & 20 & $30(12.2)$ & & \\
\hline & 21 & $18(7.3)$ & & \\
\hline & 22 & $30(12.2)$ & & \\
\hline & 23 & $3(1.2)$ & & \\
\hline
\end{tabular}

This study indicated that $59.80 \%$ of the total women got married at 16-20 years of age while only $19.50 \%$ of them got married after 20 years of age and $18.30 \%$ got married before 15 years. The mean age at first pregnancy among the women was 18.75 years $(\mathrm{SD}=1.94)$.

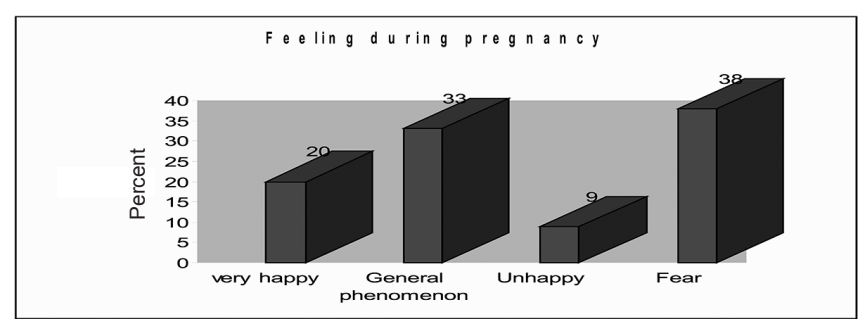

Figure 1: Feeling during Pregnancy:

Maximum respondents (38\%) had fear about their first pregnancy. The least number of pregnant women (9\%) were unhappy even at their first pregnancy.

Table 3: Beliefs regarding pregnancy and restriction of food items during pregnancy $N=246$

\begin{tabular}{|l|l|c|}
\hline \multirow{3}{*}{$\begin{array}{l}\text { Beliefs during } \\
\text { Pregnancy }\end{array}$} & Options & Frequency (\%) \\
\cline { 2 - 3 } & No beliefs & $84(34.2)$ \\
\cline { 2 - 3 } & Worship of god & $146(59.3)$ \\
\cline { 2 - 3 } & Looking child' snaps & $16(6.5)$ \\
\hline \multirow{2}{*}{$\begin{array}{l}\text { Restriction of } \\
\text { food items during } \\
\text { pregnancy }\end{array}$} & No restriction & $13(5.2)$ \\
\cline { 2 - 3 } & Restriction of food & $163(66.3)$ \\
\cline { 2 - 3 } & Restriction of fruit & $70(28.5)$ \\
\hline
\end{tabular}

Maximum (59.3\%) pregnant women believed on cultural practices as worship of god for proper growth and development of foetus where as some $(6.50 \%)$ respondents believed that looking snaps of beautiful child.

$66.30 \%$ women were restricted foods (milk, green vegetables) and $28.50 \%$ of them were restricted fruits (papaya and other yellowish) fruits during their pregnancy to prevent miscarriage.
Table 4: Association between occupation and education with antenatal care visit. $N=246$

\begin{tabular}{|c|c|c|c|c|}
\hline \multirow{2}{*}{ Occupation } & & \multicolumn{2}{|c|}{ ANTENATAL VISIT } & \multirow[b]{2}{*}{ Total } \\
\hline & & Attend & Not attend & \\
\hline & Agriculture & 141 & 48 & 189 \\
\hline & Business & 19 & 4 & 23 \\
\hline & Teacher & 12 & 0 & 12 \\
\hline & Labourer & 3 & 19 & 22 \\
\hline & \multicolumn{4}{|c|}{ Chi-square $=42.877, d f=3, p=0.000$} \\
\hline \multirow[t]{6}{*}{ Education } & Illiterate & 23 & 40 & 68 \\
\hline & Primary & 23 & 40 & 96 \\
\hline & L.Secondary & 35 & 2 & 37 \\
\hline & S.L.C. & 20 & 7 & 27 \\
\hline & Above S.L.C. & 18 & 0 & 18 \\
\hline & \multicolumn{4}{|c|}{ Chi- Square $=48.715, d f=4, P=0.000$} \\
\hline
\end{tabular}

It shows that occupation (Chi- square $=42.877, d f=3, p$ $=0.000$ ) and education (Chi-Square $=48.715, d f=4, P=$ $0.000)$ were significantly associated with antenatal practices.

\section{DISCUSSION}

Illiteracy is the greatest barrier to health development. Mother's education level even within the same socioeconomic class is a key determinant of their own health and their children health. In 1948, the declaration of human rights stated that everyone has a right to education. Yet, even today this right is being denied to millions of word population. ${ }^{5}$ The present study has found that 41.5 percent of total respondents were illiterate which is almost similar to female illiteracy rate $(42.80 \%)$ as per Nepal census $2001 .^{4,6}$ Adolescents with no education especially those in low socio-economic group began their pregnancies at early age which was similar to finding in other part of Nepal as teenage pregnant women were less educated had poor economic background. ${ }^{7}$

The study found that $59.80 \%$ of total study population got married at 16-20 years of age as compared to the result of Rapid Household Survey-Reproductive and Child Health in India $1998-99$ which showed $37 \%$ of the girls were married before attaining 18 years. ${ }^{8}$ The mean age at first pregnancy of the study population was 18.75 years $(\mathrm{SD}=1.9)$ as compared to the mean age at first pregnancy among teenagers in India was 18.1 years $(\mathrm{SD}=1.2)$. Maximum $(67 \%)$ respondents got pregnant before 20 years due to a culture of early marriage system for desire of kids early and mental satisfaction of parents as well as belief that girls could get married as soon as they attain menarche to start their sexual life, gender roles and cultural beliefs. ${ }^{8}$

Every society has their own, values, beliefs, norms, customs and practices regarding health, diseases and intake of food during pregnancy. Various factors as age, mental status, education, socio-economic status, family relationship, occupational status determine feeling during pregnancy. 
Many women have dreams about childbirth, their newborn baby and life as a new mother. They also take concern about the baby's sex. ${ }^{9}$ The study has indicated maximum (59.30\%) pregnant women believed on cultural practices as: worship of God for proper growth and development of foetus. Mother in laws of respondents forced them for carrying heavy things and restriction on food. The study also found that education and occupation were significantly associated with antenatal practices.

\section{REFERENCES}

1. Diaz-Guerrero R. The Active and Passive Syndrome. Revista Interamericana de Psicologia. 1967; 4(1).

2. Barer-Stein T. You Eat What You Are: A Study of Ethnic Food Traditions. Toronto: McClelland \& Stewart Ltd. 1979.

3. WHO. Consequences of unsafe motherhood in developing countries in 2000. Bulletin of the world health organization. 2000; 78(5).

4. Park K. Antenatal care. Park's textbook of preventive and social medicine. $17^{\text {th }}$ ed. Jabalpur. 2005; p. 417-418.

5. National institute for health and clinical excellence [homepage on the Internet]. Antenatal care: Routine care for the healthy pregnant woman. [Cited 2003 Oct 15]. Available from http://www.nice.org.uk.

6. Central Bureau of Statistic. Population census 2001. Population Monograph of Nepal. 2003; 238-243.

7. Sharma A K. Determinants of pregnancy in adolescents in Nepal. The Indian journal of pediatrics. 2002; 69(1):19-22.

8. Veenu J and kekkara T. Factors Associated with Teenage Pregnancy. IJCM. 2006; (31):2.

9. Hawaii Community College. Division of Nursing and Allied Health Student Page. Traditional Health Beliefs: Pacific Islanders cultural, Beliefs regarding pregnancy. [Cited 2005 September 15]. Available from http://www.hawcc.hawaii.edu/ nursing/ RNChinese02.html. 